\author{
M. Gojic*
}

Metalurški fakultet Sveučilišta u Zagrebu, Aleja narodnih heroja 3, 44000 Sisak

\begin{abstract}
Sažetak
Ovaj rad je pregled povijesnog razvoja znanstvenog polja metalurgije u području tehničkih znanosti od Tehničke visoke škole do osnivanja Metalurškog odjela Tehnološkog fakulteta Sveučilišta u Zagrebu. Prikazan je razvoj nastavne, znanstvene i stručne aktivnosti uključujući nastavnike koji su predavali predmet Metalurgija u Republici Hrvatskoj u razdoblju od 1919. do 1960. godine. Prikazan je također i doprinos razvoju polja metalurgije industrijskog metalurškog sektora u Republici Hrvatskoj.
\end{abstract}

Ključne riječi

Tehnička visoka škola, metalurgija, Metalurški odjel, Tehnološki fakultet

\section{Povijesni razvoj znanstvenog polja metalurgije od Tehničke visoke škole do osnivanja Metalurškog odjela Tehnološkog fakulteta Sveučilišta u Zagrebu}

\subsection{Nastavna aktivnost \\ 1.1.1. Nastava iz metalurgije na Tehničkoj visokoj školi Sveučilišta u Zagrebu}

Nastava iz znanstvenog polja metalurgija u Republici Hrvatskoj "vuče svoje korijene" iz Tehničke visoke škole Sveučilišta u Zagrebu (1919. - 1926.). ${ }^{1}$ Prof. dr. sc. Franjo Hanaman (1878. - 1941.) počeo je predavati (od akad. god. 1919./20.) predmet Mehanička tehnologija I (Metalurgija) studentima I. godine u zimskom semestru na strojarsko-inženjerskom, elektro-inženjerskom, brodograđevno-inženjerskom i brodostrojarsko-inženjerskom odjelu Tehničke visoke škole u Zagrebu do osnivanja Tehničkog fakulteta (1926.). ${ }^{2}$ Prema istom nastavnom planu na Kemijsko-inženjerskom odjelu prof. F. Hanaman počeo je predavati predmet Metalurgija na trećoj godini (zimski semestar) od akad. god. 1922./23. u okviru djelatnosti tek osnovanog Zavoda za anorgansku kemijsku tehnologiju i metalurgiju (1922.) na Kemijsko-inženjerskom odjelu Tehničke visoke škole (slika 1). Za edukaciju iz anorganske kemijske tehnologije i metalurgije služile su zbirke učila, slika, uzoraka sirovina i proizvoda anorgansko-kemijske i metalurške industrije.
Prof. F. Hanaman je diplomirao kemiju na Tehničkoj visokoj školi (TVŠ) u Beču 1899. godine i bio je asistent prof. Georga Vortmana (1854. - 1932.) na vježbama iz kvalitativne kemijske analize (1900. - 1904.) na Katedri analitičke kemije na TVŠ-u u Beču. ${ }^{3} \mathrm{Na}$ temelju niza patenata (više od 40 patenata u razdoblju 1903. - 1922.) i radom u polju metalurgije (četiri patenata iz područja zaštite željeza i čelika od korozije u razdoblju 1912. - 1920.) stekao je znanje i iskustvo vrsnoga stručnjaka iz anorganske kemije i metalurgije. Najpoznatiji svjetski patenti, zajedno s Aleksanderom Friedrichom Justom (1872. - 1937.) su o električnoj žarulji s volframovom žarnom niti. U razdoblju 1912. - 1915. radio je na Institutu za metalurgiju željeza kraj Berlina. Na Tehničkoj visokoj školi u Charlottenburgu kraj Berlina 2. svibnja 1913. godine obranio je disertaciju kao rezultat korozijskih istraživanja ponašanja željeza nakon plinskog nitriranja u struji amonijaka. Dobivene rezultate istraživanja iz disertacije zaštitio je patentima (njemački, austrijski, britanski itd.). Kasnije je radio i na novoosnovanom Središnjem zavodu za ispitivanje materijala za zrakoplovstvo kraj Beča, gdje je ustrojio metalografski laboratorij koji je vodio do kraja I. svj. rata baveći se i istraživačkim radom izradivši dva elaborata (1915. - 1918.): Aluminijski stapovi u avionskim motorima i Zamjenske slitine za ležajeve avionskih motora. Povratkom u Zagreb prof. F. Hanaman postaje jedan je od utemeljitelja Tehničke visoke škole u Zagrebu (1919.), a najveći doprinos dao je u razradi nastavnih programa tehnoloških predmeta, primarno metalurgije i anorganske kemijske tehnologije. ${ }^{3}$ Prije nego što je uredio laboratorij, vježbe iz metalurgije organizirao je u radionicama tvrtke Jugoslavenska industrija motora d. d., koju je osnovao i koje je nakratko bio i glavni ravnatelj.

Prof. F. Hanaman osnivač je (1922.) i prvi predstojnik Zavoda za anorgansku kemijsku tehnologiju i metalurgiju Ke- 
TEHNIČKA VISOKA ŠKOLA (1919. - 1926.)

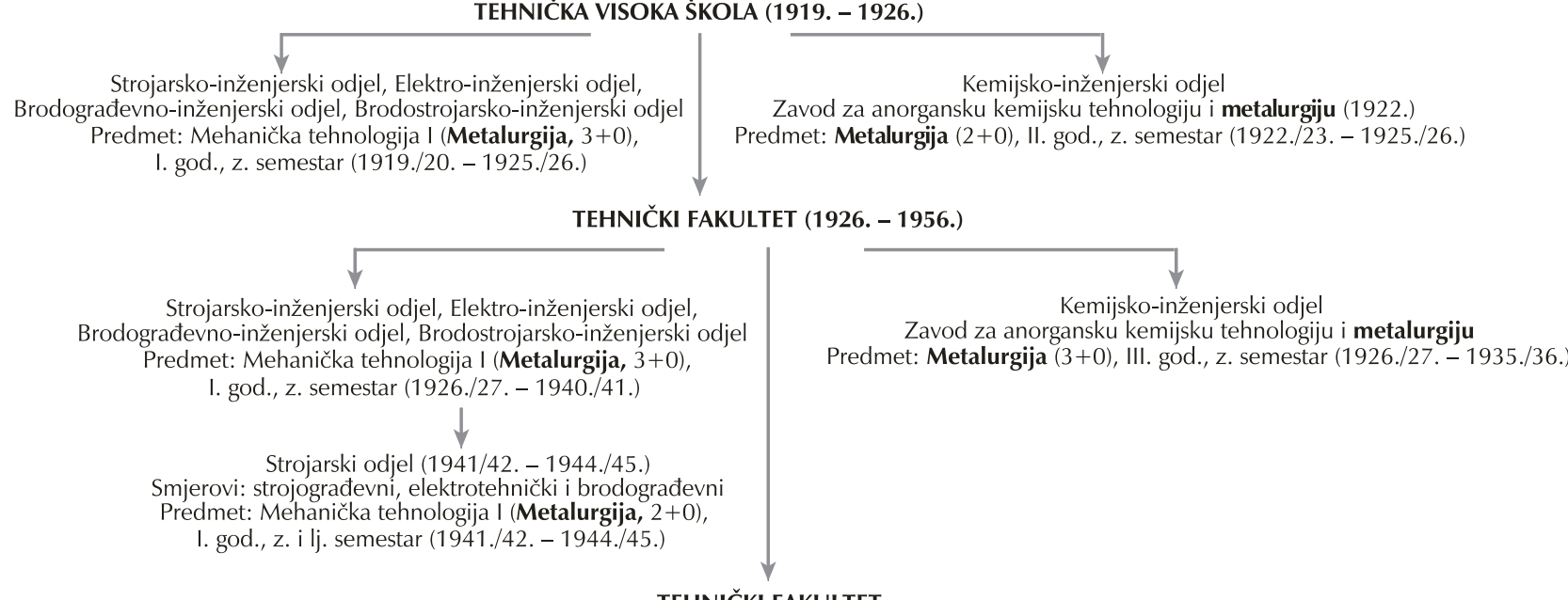

TEHNIČKI FAKULTET

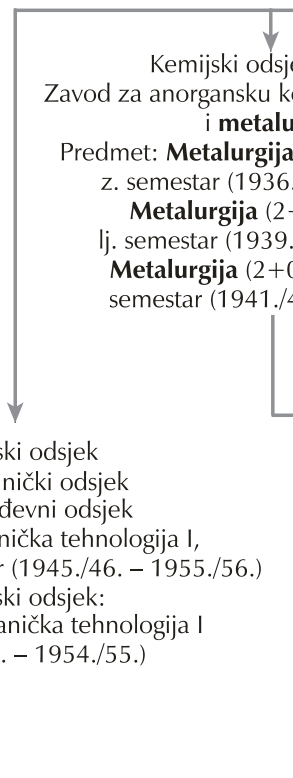

STROJARSKO-BRODOGRAĐEVNI FAKULTET (1956. - 1967.)

Zajednički predmet Metalurgija (2+2) za sve smjerove, I. godina, ljetni semestar, akad. god. 1956./57. - 1966./67. Brodograđevni odsjek d., z. i lj. semestar (1945./46. - 1955./56.) Predmet: Mehanička tehnologija (1947./48. - 1954./55.)
Elektrotehnički odsjek
Kemijsko-tehnološki odsjek (1945.), Zavod za anorgansku kemijsku tehnologiju i metalurgiju Predmet: Metalurgija (2+0), III. god., lj. semestar (1945./46. - 1946./47.) Metalurgija (3+0), III. god., z. semestar (1947./48.- 1951./52.) Metalurgija (2+0), III. god., z. semestar (1952./53. - 1955./56.) Izborni predmeti: Metalurgija željeza (2+0), IV. god., z. semestar (1951./52 - - 1955./56.) Tehnologija lakih metala (2+0), IV. god. z. semestar (1952./53. - 1955./56.)

Rudarski odjel (1945.) Predmet: Metalurgija $(2+0)$ I. god. lj. i z. semestar (1945./46.)
Predmet: Metalurgija (Opća mehanička tehnologija) 2+0, I god. Ij. semestar (1939./40. - 1940./41.)

Opća mehanička tehnologija $(2+0)$, I. god.

lj. i z. semestar (1942./43. - 1944./45.)

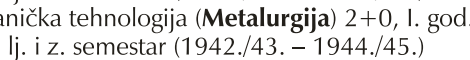

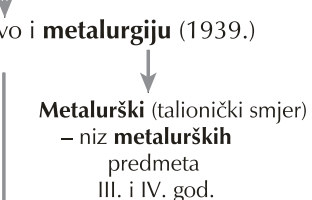

III. i IV. god.

\section{KEMIJSKO-PREHRAMBENO-RUDDARSKI FAKULTET (1956. - 1957.) \\ Kemijsko-tehnološki odsjek}

Zavod za anorgansku kemijsku tehnologiju i metalurgiju

Predmet: Metalurgija (2+0), III. god., lj. semestar (1956./57.)

Izborni predmeti: Metalurgija željeza, Metalurgija obojenih metala, Elektrometalurgija,

Metalurgija lakih metala, Fizikalna kemija metalurških procesa, (2+0), IV. god., lj. semestar (1956./57.) $\downarrow$

TEHNOLOŠKI FAKULTET (1957, - 1961.)

Kemijsko-tehnološki odjel, Zavod za anorgansku kemijsku tehnologiju i metalurgiju Predmet: Metalurgija (2+0), III. god., lj. semestar (1957./58.)

Izborni predmeti: Metalurgija željeza, Metalurgija lakih metala, (2+0), IV. god., lj. semestar (1957./58. - 1961./62.) Metalurgija obojenih metala, Fizikalna kemija metalurških procesa, (2+0), IV. god., lj. semestar (1957./58. - 1959./60.) Elektrometalurgija (1957./58. - 1960./61.)

Metalurški odjel u Sisku Tehnološkog fakulteta Sveučilišta u Zagrebu (1960.)

Slika 1 - Povijest nastave metalurgije od Tehničke visoke škole u Zagrebu do Metalurškog odjela u Sisku Tehnološkog fakulteta Sveučilišta u Zagrebu

Fig. 1 - History of teaching metallurgy - from the High Technical School in Zagreb to the Sisak Department of Metallurgy of the Zagreb Technology Faculty

mijsko-inženjerskog odjela na Tehničkoj visokoj školi. Kao materijalno neovisan, zahvaljujući svojim patentima, prof. F. Hanaman u opremanje Zavoda ulaže i vlastiti novac, a predavao je predmet Mehanička tehnologija I (Metalurgija) na pet odjela Tehničke visoke škole sve do akad. god.
1925./26. Kratki sadržaj predmeta metalurgija ${ }^{3}$ uključivao je sljedeće tematske cjeline: Uvod, Metalurgija industrije željeza i čelika, Obični i specijalni čelici, Elektročelici, Mehaničko i termičko obrađivanje željeza i čelika, Metalografija $i$ ispitivanje željeza i čelika, Kratki prikaz metalurgije ba- 
kra, olova, cinka, kositra, nikla, aluminija itd., Metalografija $i$ ispitivanje najvažnijih tehničkih metalnih legura.

\subsubsection{Nastava iz metalurgije na Tehničkom fakultetu Sveučilišta u Zagrebu}

Osnivanjem Tehničkog fakulteta Sveučilišta u Zagrebu (31. ožujka 1926.) prof. F. Hanaman nastavlja predavati predmet Mehanička tehnologija I (Metalurgija) na pet odjela Tehničkog fakulteta u Zagrebu (slika 2) od akad. god. 1926./27. do prerane smrti (23. siječnja 1941.). ${ }^{2} \mathrm{U}$ godišnjaku ${ }^{4}$ Sveučilišta u Zagrebu iz 1929. godine navedeno je: "Nastava iz kemijske tehnologije i metalurgije se sastoji u suštini u prikazivanju i vježbanju primjene teorijskih disciplina, koje je student učio u prve dvije godine svog studija na tehničku praksu. Kod predavanja se ta svrha postiže prikazom raznih kemijskih i metalurških industrija i načina na koji razne industrije rješavaju svoje probleme. Kod vježbi u laboratoriju student treba sam provoditi primjenu teorijskih disciplina na praksu i da se time privikne i nauči tehničkom načinu mišljenja."

a) Strojarski i elektrostrojarski odio.

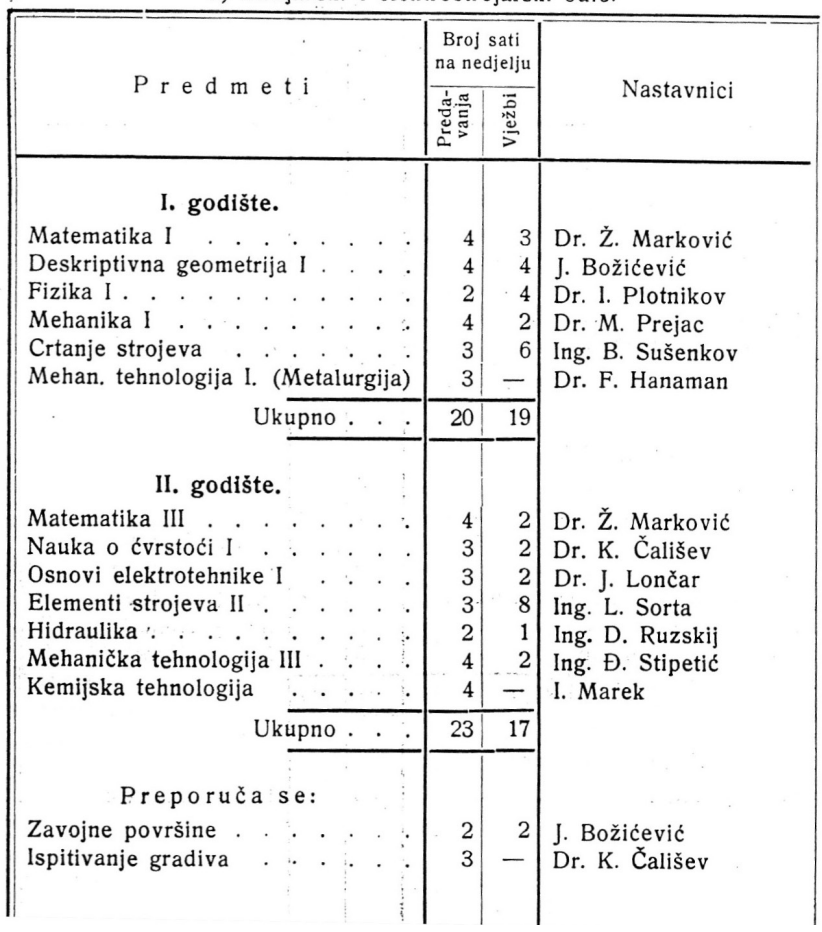

Slika 2 - Faksimil reda predavanja za prva dva godišta za strojarski i elektrostrojarski-inženjerski odjel Tehničkog fakulteta u Zagrebu za akad. god. 1926./27.

Fig. 2 - Fascimile of the list of courses for the first two years of the Department of mechanical and electro-mechanical engineering of the Technical Faculty for academic year $1926 / 27$

Osnivanjem Banovine Hrvatske 26. kolovoza 1939. godine dr. Milan Ulmanski, ministar šuma i rudnika, pozvao je prof. Hanamana da svojim znanjem pomogne izgradnji teške industrije. Prihvativši ponudu, vrlo je kratko bio predsjednik Uprave Željezare Zenica, ali se nakon smjene dr. M. Ulmanskoga povukao s te dužnosti. ${ }^{3}$ Prof. F. Hanaman je na poticaj pročelnika Rudarskog odjela Banovine Hrvatske ing. Nikole Belančića (1887. - 1954.) predložio Savjetu Tehničkog fakulteta osnivanje Odsjeka za rudarstvo i metalurgiju. ${ }^{5}$ Navedeni Odsjek osnovan je 17. studenoga 1939. godine (slika 3). Savjet Tehničkog fakulteta jednoglasno je zaključio da se odmah započne s upisima studenata u I. semestar akad. god. 1939./40. na Odsjeku za rudarstvo i metalurgiju. Odluka (Br.: Pov. 966-II-1939.) Banske vlasti Banovine Hrvatske, Odio za Prosvjetu u Zagrebu glasi: "Uslijed neophodne nužde, da se za potrebe područja Banovine Hrvatske i krajeva, koji joj gravitiraju, omogući studij rudarstva i metalurgije na Tehničkom fakultetu Sveučilišta u Zagrebu, a na osnovi Uredbe o Banovini Hrvatskoj od 26. kolovoza 1939. II čl. 2. toč. te čl. 2 Uredbe tehničkih fakulteta u Beogradu, Zagrebu i Ljubljani, po kojoj se, prema potrebama mogu na pojedinim fakultetima osnivati i novi odsjeci kao i na osnovi zaključaka Savjeta Tehničkog fakulteta Sveučilišta u Zagrebu od 31. listopada 1939. i Akademskog senata Sveučilišta u Zagrebu od 16. studenog 1939., odlučujem da se na Tehničkom fakultetu Sveučilišta u Zagrebu osnuje sa školskom godinom 1939./40. novi odsjek pod imenom: Odsjek za rudarstvo i metalurgiju". Na Odsjeku za rudarstvo i metalurgiju Tehničkog fakulteta u I. semestar akad. god. 1939./40. upisalo se 44 studenta. Pored predavanja predmeta Metalurgija $(2+0)$ u zimskom semestru studentima treće godine na Kemijskom odsjeku prof. F. Hanaman počinje predavati metalurgiju, ali pod nazivom Opća mehanička tehnologija kao dvosemestralni predmet i studentima prve godine studija rudarstva na novoosnovanom Odsjeku za rudarstvo i metalurgiju od akad. god. 1939./40. ${ }^{1}$

Osnivači Odsjeka za rudarstvo i metalurgiju su: ing. Nikola Belančić, prof. F. Hanaman i akademik Luka Marić (1899. - 1979.). Pored osnivača na Odsjeku za rudarstvo i metalurgiju kao nastavnici djelovali su: akademik Ivan Jurković (1917. - 2014.), prof. dr. sc. Jaroslav Havlaček (1879. - 1950.), akademik Miroslav Karšulin (1904. - 1984.), prof. dr. sc. Josip Baturić (1902. - 1984.), prof. dr. sc. Ivo Turina i srednjoškolski profesor Dušan Bogojević. ${ }^{1}$ Odsjek je bio smješten u dvorišnoj zgradi Tehničkog fakulteta u Zagrebu (Kačićeva 26) na petom katu. Prvi starješina Odsjeka za rudarstvo i metalurgiju je prof. F. Hanaman. Akad. god. 1939./40. otvoren je samo rudarski smjer, a vjerojatno zbog prerane smrti prof. F. Hanamana (23. siječnja 1941.) nije otvoren metalurški smjer čije je otvaranje bilo planirano za narednu akademsku godinu. Kasnije Odsjek za rudarstvo i metalurgiju mijenja naziv u Rudarski odsjek (odjel).

Drugi svjetski rat gotovo je potpuno poremetio rad ne samo na Odsjeku za rudarstvo i metalurgiju nego i na cijelom Sveučilištu u Zagrebu. Nakon smrti prof. F. Hanamana nastavu iz predmeta Mehanička tehnologija I (Metalurgija) preuzima profesor Artemije Šahnazarov (1891. - 1973.). Prema spomenici ${ }^{6}$ Tehničkog fakulteta iz 1943. godine sadržaj predmeta Mehanička tehnologija I (Metalurgija) koji je predavao prof. A. Šahnazarov sastojao se od sljedećih tematskih cjelina: Teoretski uvid u nauku o metalima i njihovim tehnološkim svojstvima; Prikaz važnijih metala i njihovih legura zajedno s industrijskim normama; Kratka teorija korozije i načini antikorozivne zaštite; Specijalna me- 
Broj 44

Odio za prosvjetu u Zagrebu

Broj Pov. 966-II-1939.

Osnivanje Odsjeka za rudarstwo $i$ metalurgiju na Tehničkom fakultetu Sveučilišta u Zagrebu.

Odlukom Bana banovine Hrvatske od I 7. studenoga I 939 . broj 78.267-II-1 939 . osnovan je na Tehničkom fakultetu Sveučilišta u Zagrebu sa školskom godinom I 939.-40. novi odsjek pod imenom »Odsjek za rudarstvo i metalurgiju«.

Za početak otvara se u odsjeku samo rudarski smjer, a upisi za prvi semestar imadu se obaviti do 20. studenoga 1939 .

Metalurgijski smjer u odsjeku otvorit će se tek u školskoi godini I 940.-I94I.

Studij na Odsjeku za rudarstvo i metalurgiju traje osam semestara.*

U Zagrebu, I7. studenoga 1939.

\section{Predstojnik :}

šk o r j a ̌́, v. r.

${ }^{*} \mathrm{~N}$ a p o m en a: - Pravilnik je objavljen u br. 2 »Narodnih Novina od 3 siječnja 1940 godine.

** N a p omena: - Odluka Bana objav ljena u br. 266 » Narodnih Novina od 23 studenoga 1939 godine.

Slika 3 - Faksimil naredbe o osnivanju Odsjeka za rudarstvo i metalurgiju

Fig. 3 - Fascimile of the decree for the establishment of the Department for mining and metallurgy

talurgija s opisom važnijih ruda za vađenje metala, njihovom pripravom te navođenjem nalazišta u Hrvatskoj; Prikaz dobivanja sirovog željeza u visokim pećima; Tvornička proizvodnja čelika; Opis trgovačkih oblika željeznog i čeličnog materijala; Kratka metalurgija bakra, aluminija, cinka, olova, kositra i magnezija; Brojčani podaci o metalima, prikaz domaćih metalurških poduzeća.

Prof. A. Šahnazarov diplomirao je 1915. godine na brodostrojarskom odjelu Politehničkog instituta u Petrogradu a od 1937. godine je redovni profesor na Tehničkom fakultetu. Bavio se teorijom rezanja na alatnim strojevima $\mathrm{i}$ ispitivanjem materijala te je bio višegodišnji predstojnik Zavoda za mehaničku tehnologiju na Strojarskom odsjeku Tehničkog fakulteta.

Prvi asistent prof. F. Hanamana od 1926. godine bio je ing. Rikard Podhorsky (1902. - 1994.), koji je diplomirao 1925. na Kemijsko-tehnološkom odjelu Tehničke visoke škole u Pragu a doktorirao je 1931. godine na Tehničkom fakultetu u Zagrebu. ${ }^{7}$ Dr. sc. R. Podhorsky je nakon smrti prof. Hanamana preuzeo vodstvo Zavoda za anorgansku kemijsku tehnologiju i metalurgiju i nastavu iz predmeta Anorganska kemijska tehnologija (uz prekid 1943. - 1945.), uz napomenu da je na Kemijsko-tehnološkom studiju Tehničkog fakulteta 1936. uveo predmet: Kemijsko-tehnološko računanje, objavivši u dva izdanja (1937. i 1947.) skripta: Kemijsko-tehnološko računanje.
Može se ustvrditi da su prerana smrt prof. F. Hanamana i Drugi svjetski rat poremetili razvoj studija metalurgije na Tehničkom fakultetu Sveučilišta u Zagrebu, ali jedan od razloga je vjerojatno i nedostatak potrebnih nastavnika za stručne metalurške predmete. Nedostatak kadrova najbolje ilustrira red predavanja ${ }^{2}$ za akad. god. 1944./45. na talioničkom smjeru Rudarskog odsjeka Tehničkog fakulteta iz kojeg se vidi da je nastava iz niza stručnih metalurških predmeta na trećoj i četvrtoj godini povjerena dvojici profesora: Epaminondasu Ključenku: Priprema i mehaničko oplemenjivanje ruda i ugljena, briketiranje i koksanje, Metalurgija sirovog željeza, Metalurgija kovanog željeza $i$ čelika, Specijalne vrste čelika, Talioničko oblikovanje željeza i čelika i Kserksesu Ključenku: Metalurgija neželjeznih kovina, Elektrometalurgija, Talioničko oblikovanje neželjeznih kovina.

Prema redu predavanja od akad. god. 1945./46. Odsjek za rudarstvo i metalurgiju mijenja naziv u Rudarski odjel, a prof. A. Šahnazarov nastavlja predavati dvosemestralni predmet Metalurgija na Rudarskom odjelu u prvoj godini studija i na Kemijskom odjelu na trećoj godini studija (slika 1). Nakon toga se na Rudarskom odjelu više ne predaje predmet Metalurgija. Od akad. god. 1952./53. na Kemijsko-tehnološkom odsjeku Tehničkog fakulteta prof. A. Šahnazarov predaje predmet Metalurgija na trećoj godini, ali samo u zimskom semestru, sve do kraja djelovanja Tehničkog fakulteta (1956.), tj. pretvaranja njegovih odsjeka u posebne fakultete.

Na Strojarskom odsjeku Tehničkog fakulteta 1950. godine osnovana je Katedra za lijevanje metala, a od akad. god. 1945./46. predmet Mehanička tehnologija I počinje predavati honorarni nastavnik Niko Malešević (1901. - 1982.), i od tada se, prema redovima predavanja, gubi riječ metalurgija iz naziva predmeta na Strojarskom odsjeku sve do diobe Tehničkog fakulteta (1956.) ${ }^{1}$. Na Elektrotehničkom odsjeku predmet Mehanička tehnologija I predaje prof. A. Šahnazarov, dok na brodograđevnom odsjeku isti predmet predaje prof. dr. sc. Josip Hribar (1907. - 1993.). Prof. J. Hribar je diplomirao 1933. godine, doktorirao 1944. na Tehničkom fakultetu u Zagrebu, bio je stručnjak, osim ostalog, za plastičnu preradu metalnih materijala.

Od akad. god. 1951./52. u ljetnom semestru četvrte godine uveden je izborni predmet Metalurgija željeza, koji predaje studentima jedne (anorgansko-tehnološka skupina) od tri skupine Kemijsko-tehnološkog odsjeka Tehničkog fakulteta honorarni nastavnik Vladimir Logomerac (1914. - 1980.), tadašnji voditelj Tehničke kontrole MK Željezare Sisak. ${ }^{1}$ Tada se za studente iste skupine uvodi izborni predmet Tehnologija lakih metala, ali bez navođenja imena nastavnika u redu predavanja.

\subsubsection{Nastava iz metalurgije na Strojarsko-brodograđevnom i Tehnološkom fakultetu}

Sabor NR Hrvatske 26. travnja 1956. donio je Odluku o pretvaranju odsjeka Tehničkog fakulteta Sveučilišta u Zagrebu u posebne fakultete (Arhitektonsko-građevinsko-geodetski fakultet, Strojarsko-brodograđevni fakultet, Elektrotehnički 
fakultet, Kemijsko-prehrambeno-rudarski fakultet). Prema redovima predavanja² ${ }^{2}(1956 . / 57 .-1966 . / 67$.$) na Strojar-$ sko-brodograđevnom fakultetu se predaje zajednički predmet pod nazivom Metalurgija za sve smjerove studentima I. godine u ljetnom semestru a predmetni nastavnici su profesori Niko Malešević (1956./57. - 1961./62.) i Mladen Banovac (1962./63. - 1966./67.). Prof. Niko Malešević, koji je diplomirao strojarstvo na Tehničkoj visokoj školi u Zagrebu (1926.), bio je stručnjak za ljevarstvo, vodio je ljevaonicu u Tvornici željezničkih vozila Gredelj (1935. - 1943.) i bio je voditelj na početku rada Instituta za lake metale u Zagrebu i dugogodišnji nastavnik Fakulteta strojarstva i brodogradnje (FSB) u Zagrebu (1946. - 1972.). Prof. M. Banovac je diplomirao strojarstvo 1940. godine na Strojarskom odsjeku Tehničkog fakulteta te je predavao niz predmeta (Osnove znanosti o metalima, Metalurgija, Industrijske peći) na Katedri za znanost o metalima i ljevarstvo.

Na Kemijsko-tehnološkom odsjeku Kemijsko-prehrambeno-rudarskog fakulteta, odnosno od akad. god. 1957./58. na Tehnološkom fakultetu, prof. A. Šahnazarov nastavlja predavati obvezatni predmet Metalurgija na trećoj godini u ljetnom semestru sve do akad. god. 1957./58., a honorarni nastavnik V. Logomerac nastavlja predavati izborni predmet Metalurgija željeza (slika 1) studentima anorgansko-tehnološke skupine Tehnološkog fakulteta zaključno s akad. god. 1961./62. Od akad. god. 1956./57. godine kao honorarni nastavnik dr. sc. Branko Lovreček (1920. - 1996.) predavao je studentima anorgansko-tehnološke skupine Kemijsko-tehnološkog odsjeka Kemijsko-prehrambeno-rudarskog fakulteta novi izborni predmet na 4. godini u VIII. semestru: Elektrometalurgija. Isti je predmet dr. sc. B. Lovreček nastavio predavati i na Kemijsko-tehnološkom odjelu Tehnološkog fakulteta sve do akad. god. 1960./61. ${ }^{2}$ Predmeti Fizikalna kemija metalurških procesa i Metalurgija obojenih metala na popisu su predmeta u redovima predavanja (ali bez navođenja nositelja kolegija) zaključno s akad. god. 1959./60., dok je predmet Metalurgija lakih metala na popisu izbornih predmeta (bez navođenja nositelja kolegija) za studente anorgansko-tehnološke skupine Kemijsko-tehnološkog odjela Tehnološkog fakulteta, zaključno s akad. god. 1961./62.

\subsection{Znanstveno-istraživačka i stručna aktivnost}

Znanstveno-istraživačka i stručna aktivnost u Republici Hrvatskoj iz znanstvenog polja metalurgija u području tehničkih znanosti je, u nekoj mjeri, postojala i prije formalnog osnivanja Metalurškog odjela u Sisku Tehnološkog fakulteta Sveučilišta u Zagrebu, odnosno kasnije na Metalurškom fakultetu u Sisku. Istraživanja su se odvijala u okviru osnovanog (1922.) Zavoda za anorgansku kemiju i metalurgiju, kao prvog inženjerskog zavoda na Tehničkoj visokoj školi. Zavod je bio smješten na dijelu prvoga kata i podruma zgrade Kemijskog instituta na Marulićevu trgu 20 u Zagrebu, a sastojao se iz studentske radionice s 20 radnih mjesta, kabineta i prostorija za nadstojnika i asistente, knjižnice Zavoda, prostorije za kalorimetrijsku i elementarnu analizu goriva, nusprostorije za digestore, vagaonice, prostorija za pripremu metalografskih uzoraka i za mikroskope, tamne komore za fotografski rad te mehaničke radionice i skladišta u podrumu. Zavod je imao veći broj uređaja za kemijsku, toplinsku i mikroskopsku analizu materijala (vage, kalorimetre za čvrsta i plinovita goriva, uređaj za elektrolizu, električne peći, uređaje za analizu plinova, veliku električnu peć s grijanjem platinskim otporom, uređaje za brušenje i poliranje metalografskih uzoraka, optički Reichertov mikroskop itd.). ${ }^{1}$ Knjižnica Zavoda bila je jedna od najbogatijih na Tehničkoj visokoj školi (oko 600 naslova) i dobivala je velik broj i stručnih metalurških časopisa: Stahl und Eisen (od 1913.), Zeitschrift für Metallkunde (od 1920.), Journal of the Institute of Metals (od 1926.), Chemical \& Metallurgical Engineering (od 1927.), La Metallurgia Italiana (od 1928.), Canadian Chemistry and Metallurgy (od 1928.), Rudarski i topioničarski vjesnik (od 1929.) itd.

Utemeljitelj Zavoda za anorgansku kemijsku tehnologiju i metalurgiju Tehničke visoke škole prof. F. Hanaman u znanstvenu literaturu ušao je s radom: Ein Apparat für Elektroanalytische Zwecke koji je objavljen 1902. godine u vodećem njemačkom časopisu iz tog područja Zeitscrift für Elektrochemie. Rezultati njegove disertacije pod nazivom s naslovnice disertacije: ${ }^{3}$ Uber Rostversuche mit nitriertem Eisen (Tehnische Universität Berlin-Charlottenburg, 1913.), koju je izdao kao brošuru, uvršteni su u literaturu o pojavi "pasivnosti" željeza. I njegov habilitacijski rad za docenta (1915.) pod naslovom: Über Cer-Legierungen die Cer-Kupfer Legierungen und ihre Konstitution (O legiranju s cerijem, slitine cerija i bakra i njihova struktura) koji je objavio u časopisu Internat. Zeitschrift für Metallographie (1915.) uvršten je u literaturu o binarnim legurama: Friedrich $F$. Regelsberger, Chemische Technologie der Leichtmetalle und ihrer Legierungen, Springer-Verlag, Berlin Heidelberg, 1926.

Nakon osnivanja i opremanja Zavoda za anorgansku kemijsku tehnologiju i metalurgiju Tehničke visoke škole provode se znanstvena istraživanja iz tzv. opće kemijske tehnologije, uključujući i polje metalurgije. Pored prof. F. Hanamana, kao predstojnika Zavoda, u to vrijeme djeluju kao asistenti inženjeri: Rade Broz (1922. - 1924.), Wanda Gomiršek (1924. - 1926.), Rikard Podhorsky (od 1926.), dr. Vladimir Kostjev (od 1926.) i Drago Barbetti (od 1928.). ${ }^{1}$ Do 1929. godine izrađeno je oko 20-ak diplomskih radova, uključujući i ona iz polja metalurgije. U razdoblju 1922. - 1924. provedena su znanstvena istraživanja iz polja metalurgije u okviru izrade disertacije pod naslovom: Naši boksiti i njihova primjena kod Bayerovog procesa, koju je obranio asistent na Zavodu za anorgansku kemijsku tehnologiju i metalurgiju ing. Rade Broz 1925. godine na Kemijsko-inženjerskom odjelu Tehničke visoke škole.

lako je nerado objavljivao radove, neki od objavljenih radova prof. F. Hanamana iz polja metalurgije u časopisu Arhiv za hemiju i farmaciju su: ${ }^{3}$ Prilog ispitivanju metalnog materijala pomoću metalografskih metoda (1927.), Elektrohemijska i elektrometalurška industrija Norveške (1928.), O talištu čistog hroma, (1931.), Čelik dvostruke čvrstoće (1935.), Svjetska nalazišta i proizvodnja manganske rude (1936.) itd.

U to vrijeme (kao što je to i danas) pored znanstvenih istraživanja važnu je ulogu imalo traženje, uspostavljanje i jačanje kontakata radi razmjene iskustva i tehničkih in- 
formacija iz inozemstva7. Asistent prof. F. Hanamana ing. R. Podhorsky na početku istraživačke karijere provodio je opsežna istraživanja iz korozije metala, osobito cinka i željeza, a posebno je proučavao tzv. solni efekt kod korozije tih kovina u neutralnim solnim otopinama. On je, kao veliki znanstveni entuzijast i poliglot (govorio je osam svjetskih jezika), imao važnu ulogu u podizanju razine niza tehničkih znanja (uključujući i znanstveno polje metalurgije) jer je sa svojih brojnih stručnih putovanja u inozemstvo i iz stranih znanstveno-stručnih časopisa prenosio najnovije znanstvene i stručne spoznaje putem javnih predavanja uz objavljivanje prikaza najnovijih tehničkih dostignuća (objavio je preko 300 članaka u časopisima), posebice u razdoblju 1926. - 1941. Objavio je više od 60 prikaza iz polja metalurgije u časopisima Tehnički list, Arhiv za hemiju i farmaciju, Arhiv za hemiju i tehnologiju, kao npr.: Neke vrste čelika, Produkcija čelika u Njemačkoj, Direktno dobivanje čelika iz rudače, Kisik u čeliku, Svjetska proizvodnja aluminija, Berilium-bronce, Specijalne mjedi, Kemijska i metalurgijska industrija Švedske, Proizvodnja sirovog željeza u električnoj peći s pomoću koksa itd. Od 1953. do 1959. godine prof. dr. sc. R. Podhorsky radio je kao znanstveni suradnik u Institutu za lake metale u Zagrebu.

Akademik Miroslav Karšulin, koji je diplomirao 1928. godine na Tehničkom fakultetu u Zagrebu, započeo je svoja znanstvena istraživanja o periodičkim titrajima potencijala željeza u nekim otopinama ${ }^{8}$. Doktorirao je 1932. na Tehničkom fakultetu u Zagrebu iz polja kemije. Od akad. god. 1932./33. ugovorni je asistent u Zavodu za anorgansku kemijsku tehnologiju i metalurgiju a imao je i široke znanstveno-istraživačke interese, uključujući i polje metalurgije. Krajem 1940-ih akademik M. Karšulin bavio se istraživanjem minerološkog sastava boksita, utvrdivši da naši boksiti sadrže previše silikata, što je objavio 1949. godine u JAZU-u pod naslovom: Studije o boksitima. Od 1952. godine akademik $M$. Karšulin primarno se bavi korozijom (olova, željeza, aluminija, čelika u naftnoj industriji i kotlogradnji, zaštitom metalnih materijala od korozije) s naglaskom na rješavanju praktičnih problema. Akademik M. Karšulin naročito je potaknuo razvoj metalurške industrije, ispitivanjem domaćih bentonitnih glina za ljevačke pijeske, eksperimentima koksiranja ugljena iz Raše za metalurške svrhe itd. Rezultate istraživanja objavljivao je u svjetskim (Zeitschrift für Electrochemie, Werkstoffe und Korrosion itd.) i domaćim časopisima (Arhiv za kemiju i tehnologiju, Nafta, Rad JAZU itd.).

Prof. dr. sc. Branko Lovreček (1920. - 1996.), koji je diplomirao 1943. godine na Tehničkom fakultetu u Zagrebu, a doktorsku disertaciju je obranio 1952. godine, među ostalim se u dijelu svoje znanstveno-istraživačke karijere bavio i istraživanjima u polju metalurgije. Kao rezultat tih istraživanja prof. B. Lovreček je u časopisu Kemija $u$ industriji objavio radove: Elektrometalurška prerada oksidnih antimonskih rudača (1953.), Elektrolitičko dobivanje metalnog mangana iz domaćih sirovina (1955.) itd. ${ }^{9}$ Osim u navedenim časopisima rezultati istraživanja objavljivali su se i u časopisu Ljevarstvo (od 1954.), čiji je izdavač Društvo ljevača NR Hrvatske. Prof. N. Malešević, kao stručnjak iz znanstvene discipline ljevarstva, objavio je priručnik: Materijali za kalupljenje, Nakladni zavod Hrvatske, Zagreb, 1947., kao i Osnove nauke o metalima dio 1 (1956.) i dio 2 (1959.) u izdanju Sveučilišta u Zagrebu. U časopisu Lje- varstvo objavio je niz radova iz polja metalurgije: Specijalizacija ljevaonica (1955.), Operativna kontrola sastava litine za sivi lijev (1956.) itd. Prof. Malešević je u više nastavaka u časopisu Ljevarstvo (1956. - 1960.) obradio sastav i dao prikaz metalografije željeznih ljevova. U časopisu Strojarstvo (1959.) objavljeni su i radovi: Sivi lijev kao konstrukcioni materijal, Kalenje alatnih čelika u toplim kupkama itd.

U okviru Instituta za lake metale (ILAM) u Zagrebu primarno se radilo na istraživanju obojenih metala, uključujući njihovo lijevanje, koroziju i zaštitu, zavarivanje itd. U ILAM-u se početkom 1950.-ih istraživalo i na bezdanom lijevanju aluminija predviđenom za valjanje. U tom kontekstu u časopisu Ljevarstvo objavljeni su radovi: Utjecaj pješčanog kalupa na mjehurićavost odljeva (1955.), O osjetljivosti ljevačkog pijeska (1956.) u časopisu Strojarstvo (1959.): Korozija željeza i alitiranje, a u Biltenu Društva za tehniku zavarivanja (DTZ) NR Hrvatske (od 1960. časopis Zavarivanje) objavljeni su 1959. godine radovi: Lokalna $i$ operativna zavarljivost aluminijskih legura-ispitivanje utjecaja metalurških faktora i načina rada na mehanička svojstva zavarenog spoja, Korozija aluminijskih proizvoda i o načinu površinskog zaštićivanja, Lijepljenje aluminija itd.

Istraživanja na upotrebi crvenog mulja kao potencijalnog uloška za proizvodnju sivog sirovog željeza sa što višim sadržajem silicija odvijala su se (1945. - 1950.) u elektro peći snage 1500 kVA u Tvornici elektrode i ferolegura (TEF) u Šibeniku. ${ }^{10} \mathrm{Na}$ temelju iskustava s elektro peći iz Šibenika u industrijskoj visokoj peći (VP) 1, koja je bila pred remontom, (korisni volumen od $65 \mathrm{~m}^{3}$ ) Sektora za istraživanje Željezare Sisak upotrebljavalo se crveni mulj za dobivanje sirova željeza (1950. - 1960.).

U Željezari Sisak se 1953. godine započelo s istraživanjem sinteriranja (aglomeriranje) i peletiziranja crvenog mulja na poluindustrijskim tavama za sinteriranje (Greenawalt). Također je rađena istraživanja pripreme zasipa za visoku peć uz samo sušenje crvenog mulja, a samo taljenje provedeno je u poluindustrijskoj visokoj peći Željezare Sisak. U tom smislu su za Sektor za istraživanje Željezare Sisak izrađeni izvještaji: Okrupnjavanje crvenog mulja: sinterovanje, peletiziranje i briketiranje (1957.), Uslovi izluživanja trosaka dobivenih topljenjem crvenog mulja sumpornom kiselinom i solvent ekstrakcija dobivenih otopina (1958.) itd. ${ }^{10} \mathrm{U}$ okviru Sektora za istraživanje Željezare Sisak započelo se krajem 1950-ih godina na pripremi i preradi željeznih ruda. Istraživanja su se provodila pod nazivom: Pokusna visoka peć četiri, a odnosila su se na istraživanje domaćeg koksa. Rezultate istraživanja prihvatilo je i Udruženje jugoslavenskih željezara (osnovano 1951.) i ta su se rješenja počela primjenjivati i u drugim željezarama. Zaposlenici Željezare Sisak krajem 1950.-ih godina objavljivali su rezultate znanstveno-istraživačkog i stručnog rada ostvarenih u industrijskim pogonima u časopisima (Ljevarstvo, Strojarstvo, Bilten Društva za tehniku zavarivanja, od 1960. godine časopis Zavarivanje). U tim objavljenim radovima prezentirana su stečena iskustva iz čišćenja klasično lijevanih čeličnih ingota, dati su prikazi proizvodnje i proizvodnog asortimana bešavnih cijevi te proizvodnje kokila za klasično lijevanje čelika.

Treba napomenuti da su i prvi nastavnici stručnih metalurških predmeta i prije osnivanja (1960.) Metalurškog odjela 
u Sisku Tehnološkog fakulteta Sveučilišta u Zagrebu imali znanstveno-istraživačkog, stručnog i nastavnog iskustva iz znanstvenog polja metalurgije. ${ }^{11}$ Inženjer Lujo Chloupek, koji je 1923. godine diplomirao na Metalurškom odjelu Visoke rudarske škole u Pribramu (Češka), praktična metalurška je iskustva stjecao radeći u željezarama Dovhoje (Češka), Vareš, Zenica, Sisak itd. Stručne radove iz proizvodnje sirovog željeza, visokih peći te uporabe i proizvodnje koksa objavljivao je (1949. - 1951.) u časopisu Teška industrija. U razdoblju 1949. - 1960. bavio se istraživanjima iz područja proizvodnje sirovog željeza i osnovnih metalurških sirovina a bio je i glavni inženjer (1951. - 1956.) MK Željezare Sisak. Među njegovim objavljenim radovima treba istaknuti: Priprema i topljenje vareških ruda u visokoj peći obzirom na domaći koks (1951.), Problematika domaćeg koksa (1955.), Rezultati proba topljenja sirovog željeza u visokim pećima upotrebom koksa proizvedenog uz dodatak jugoslavenskih goriva (1960.) itd. Kao honorarni nastavnik na Tehnološkom fakultetu u Beogradu predavao je (akad. god. 1950./51.) predmet: Projektiranje visokih i SM-peći. Izradio je više studija za Udruženje jugoslavenskih željezara u Beogradu i za Ekonomski institut u Zagrebu. Autor je udžbenika Proizvodnja sirovog gvožđa (1954.).

Znanstveno-stručna istraživanja inženjera Vladimira Logomerca, koji je diplomirao 1938. godine na Kemijsko-inženjerskom odsjeku Tehničkog fakulteta Sveučilišta u Zagrebu, su iz područja iskorištavanja siromašnih boksita, laterita i crvenog mulja (1940. godine), metalurške pripreme rudnih sirovina, uključujući magnetizirajuće prženje, magnetnu separaciju i okrupnjavanje ruda željeza (1950. - 1960.) itd. Ing. V. Logomerac je metalurška iskustva stjecao radeći u željezarama Zenica, Vareš i Sisak, Ministarstvu Hrvatske za metalurški sektor itd. ${ }^{1}$ Od akad. god. 1951./52. bio je i honorarni nastavnik izbornog predmeta Metalurgija željeza na Kemijsko-tehnološkom odsjeku Tehničkog fakulteta u Zagrebu. Odlukom Sabora NR Hrvatske ing. V. Logomerac je 12. svibnja 1956. godine imenovan (kao jedan od deset članova) članom Fakultetskog savjeta novoformiranog Kemijsko-prehrambenog-rudarskog fakulteta, nastalog iz više odsjeka Tehničkog fakulteta. Istraživao je u MK Zeljezari Sisak (u odjelu Tehničke kontrole, a kasnije u Sektoru za istraživanje) na području crvenog mulja, izluživanja dobivene troske i na solvent ekstrakciji konstituenata iz kiselih otopina luženjem (1955. - 1960.). Teorijski je razradio, a zatim i praktično potvrdio tijekom eksperimenata, mogućnost potpunog razaranja barita u sideritnoj željezovitoj rudi tijekom procesa sinteriranja (1960.). Istraživao je i u području oplemenjivanja željezovitih ruda (1960.) itd.

Inženjer Pavle Pavlović, koji je diplomirao 1945. godine na Bergakademie Freiberg (Njemačka), bio je 1945. godine pomoćni asistent poznatog njemačkog metalurga (posebice u razvoju austenitnog nehrđajućeg $18 \mathrm{Cr}$-8Ni čelika) prof. Eduarda Maurera (1886. - 1969.) na Institutu za željezo i čelik Bergakademie Freiberg. ${ }^{1}$ Ing. P. Pavlović je metalurška iskustva stjecao radeći u željezarama Smederevo, Zenica i Sisak. Dolaskom u MK Željezara Sisak (1957.) priredio je za Udruženje jugoslavenskih željezara elaborat: Kapacitet elektropeći za topljenje čelika. U razdoblju 1959. - 1960. ing. P. Pavlović izradio je studiju za povećanje kapaciteta Siemens-Martinovih peći i investicijski program rekonstrukcije čeličane u MK Željezara Sisak.

\subsection{Doprinos razvoju polja metalurgije iz gospodarskog metalurškog sektora}

Razvoju znanstvenog polja metalurgije doprinos je dao i razvoj industrijskog metalurškog sektora koji je nakon I. svj. rata obnovljen i počeo se dalje razvijati. Nastavlja se vađenje rude željeza u Trgovskoj gori i proizvodnja sirovog željeza u talionicama Topusko i Bešlincu, nadomak grada Siska. Proizvodnja sirovog željeza u svim talionicama u 1939. godini iznosila je oko 5 kt. Nastavlja se i proizvodnja u nizu ljevaonica u: Rijeci, Osijeku, Zagrebu, Varaždinu, Požegi itd. Između dva svjetska rata na zagrebačkom području je "niklo" oko 40-ak ljevaonica (nekoliko industrijskih, ali primarno obrtničke razine proizvodnje). ${ }^{12}$ Metalurška proizvodnja nastavila se odvijati u Tvornici elektroda i ferolegura (TEF) u Šibeniku (osnovanoj 1900. godine), ${ }^{13}$ tvornici karbida i ferolegura Dalmacija Dugi rat (osnovana 1908. godine) itd. U Republici Hrvatskoj (a i u Jugoslaviji) su 1937. godine u Lozovcu pored Šibenika odliveni prvi aluminijski blokovi u tvornici "Ivanal", a elektroliza glinice započela je 1939. godine. ${ }^{14}$ Godine 1940. proizvedeno je oko 2 kt tekućeg aluminija i oko 2,5 kt glinice. U Sisku 1939. godine s radom počinje Talionica Caprag, preteča nekadašnje Željezare Sisak, planiranog godišnjeg kapaciteta 25 kt sirova željeza. Tijekom 1940. godine u talionici Caprag na visokim pećima (VP) proizvedeno je oko 19,5 kt bijelog sirova željeza namijenjenog za proizvodnju čelika. Uoči II. svj. rata u 20-ak ljevaonica proizvelo se oko 9 kt odljevaka. ${ }^{15}$ Drugi svjetski rat osjetno je smanjio ili ugasio metaluršku proizvodnju zbog ratnih događanja, manjka radne snage, otežane dobave sirovina, energije itd. Nakon II. svj. rata obnavlja se prijeratni metalurški sektor i iznova izgrađuje niz novih industrijskih metalurških tvrtki (Željezara Sisak, TLM Šibenik, niz ljevaonica u okviru brodogradilišta i većih metaloprerađivačkih poduzeća itd.). Mnogo se ulagalo u rekonstrukciju i modernizaciju postrojenja, ali i u izgradnju novim investicijama u ekstraktivni metalurški segment (proizvodnja čelika, ferolegura, odljevaka itd.) te u valjaonički sektor (proizvodnja bešavnih cijevi, valjani i prešani Al-proizvodi, finalizacija valjanih proizvoda itd.). Sve navedene tvrtke su za neposrednu proizvodnju imale pogonske i/ili centralne laboratorije za ocjenu sirovina te poluproizvoda ili gotovih proizvoda. Godine 1960. Željezara Sisak proizvela je 358,5 kt metalurških proizvoda (sirovo željezo, čelik, bešavne cijevi, odljevci), ${ }^{16}$ TLM Šibenik je proizveo 1,836 kt tekućeg aluminija i 18,401 kt Al-valjanih i prešanih proizvoda, ${ }^{14}$ TEF Šibenik proizveo je oko 23 kt ferolegura, elektroda i anoda, ${ }^{13}$ dok je ukupna proizvodnja odljevaka bila oko 60 kt.

\subsection{Pretpostavke za osnivanje Metalurškog odjela Tehnološkog fakulteta}

Brzi gospodarski razvoj sredinom 20. stoljeća nametnuo je potrebu bržeg osposobljavanja visokostručnih i specijaliziranih kadrova u Republici Hrvatskoj u području tehničkih znanosti, uključujući i znanstveno polje metalurgije. U to vrijeme tadašnji visokoškolski sustavi na polju metalurgije u Ljubljani i Beogradu nisu nudili dovoljan broj metalurškog kadra. U razdoblju 1957. - 1961. iskazana je potreba za 276 inženjera metalurgije za gospodarske metalurške subjekte bivše Jugoslavije. ${ }^{17}$ Pripremne aktivnosti s ciljem odvijanja visokoškolske nastave u Sisku počinju 1958. godine 
na poticaj gospodarskih subjekata iz Siska. Visokoškolska nastava Odjela Tehnološkog fakulteta u Sisku započela je akad. god. 1960./61. u skladu s odlukom Sabora NR Hrvatske od 7. srpnja 1960. godine, kojom se u sastavu Tehnološkog fakulteta Sveučilišta u Zagrebu osnivaju Metalurški odjel i Tehnološko-pogonski odjel za naftu u Sisku. Time se Sisak, sa svojim industrijskim i kadrovskim potencijalima, svrstao u gradove s visokoškolskim institucijama, za osposobljavanje diplomiranih inženjera metalurgije i diplomiranih inženjera kemijske tehnologije za naftu i petrokemiju. Tek se tada na jednom mjestu počinje stvarati jezgra znanstveno-nastavnih i stručnih djelatnika čija su istraživanja sustavno usmjerena na znanstveno polje metalurgija u području tehničkih znanosti. ${ }^{11}$

\section{Literatura}

\section{References}

1. M. Gojić, 50 godina studija metalurgije (monografija 1960. - 2010.), Metalurški fakultet, Sisak, 2010.

2. Redovi predavanja Sveučilišta u Zagrebu, Sveučilište u Zagrebu, 1919./20. - 1960./61.

3. Edicija istaknuti profesori, Franjo Hanaman, Fakultet kemijskog inženjerstva i tehnologije, Zagreb, 2017.

4. Godišnjak Sveučilišta u Zagrebu, 1924./25. - 1928./29., Nadbiskupska tiskara, Zagreb, 1929.

5. Zbirka zakona i uredaba, svezak I.-XII, Zagreb, 1940.

6. S. Horvat, Spomenica 1942. - 1943., Zagreb, 1943.

7. Edicija istaknuti profesori, Rikard Podhorsky, Fakultet kemij- skog inženjerstva i tehnologije i Hinus, Zagreb, 2002.

8. Edicija istaknuti profesori, Miroslav Karšulin, Fakultet kemijskog inženjerstva i tehnologije i Hinus, Zagreb, 2004.

9. V. Gržetić, Bibliografija 1919. - 1993., Fakultet kemijskog inženjerstva i tehnologije, Zagreb, 1995.

10. V. Logomerac, Primjena pirometalurškog i hidrometalurškog postupka, te solvent ekstrakcije u razradi kompleksnog postupka za preradu crvenog mulja, a u cilju dobivanja svih u njemu sadržanih korisnih sastojaka, disertacija, OOUR Metalurško inženjerstvo Tehnološkog fakultet u Zagrebu, 1976., str. 89-169.

11. Monografija Sveučilišta u Zagrebu 1669. - 2019., urednica Mirjana Polić Bobić, (Prilozi u monografiji M. Gojić: Metalurški fakultet, str. 214-217; Metalurgija, str. 410-414), Sveučilište u Zagrebu, Zagreb, 2019.

12. F. Debeuc, Ljevaonice grada Zagreba i njegove okolice od početka XIX stoljeća do drugog svjetskog rata, Ljevarstvo $\mathbf{1 6}$ (1)(1969) 26-49.

13. Tvornice elektroda i ferolegura Šibenik-monografija povodom 75. godišnjice, TEF Šibenik, Šibenik, 1975.

14. M. Šmit, Izgradnja hrvatske aluminijske industrije, TLM Šibenik, Šibenik, 1997.

15. Hrvatska tehnička enciklopedija 1, LZ Miroslav Krleža, Zagreb, 2018.

16. Z. Čepo, Željezara Sisak 1938. - 1978., treće prerađeno i dopunjeno izdanje, SOUR Metalurški kombinat "Željezara Sisak", Sisak, 1978.

17. Da. Maljković, Razvitak visokoškolske izobrazbe i organiziranog rada u Sisku, Znanstveni skup: Sisak - više od 2000 godina postojanja, Sisak, 5. - 7. listopada 1989., Radovi Leksikografskoga zavoda "Miroslav Krleža", knj. 3, Zagreb, 1993., str. 23-36.

\section{SUMMARY}

History of the Development of the Metallurgy Scientific Field From the High Technical School to the Formation of the Department for Metallurgy of the Zagreb Technology Faculty

$$
\text { Mirko Gojić }
$$

This work reviews the development of the scientific field of metallurgy within the domain of technical science - from the High Technical School to the formation of the Department for Metallurgy, Zagreb Technology Faculty. Also presented is the development of teaching, scientific, and professional activities, including metallurgy teachers in the Republic of Croatia during the 1919-1960 period. The contribution of the metallurgical industry to the development of metallurgy as a scientific field in the Republic of Croatia is shown.

\section{Keywords}

High Technical School, metallurgy, Department for Metallurgy, Faculty of Technology

University of Zagreb

Faculty of Metallurgy Sisak

Aleja narodnih heroja 3

44000 Sisak, Croatia
Review

Received December 21, 2020

Accepted January 15, 2021 